\title{
Role of Gastric Emptying in Symptoms of Gastroparesis
}

\author{
Asad Jehangir and Henry P. Parkman *
}

Section of Gastroenterology, Department of Medicine, Temple University School of Medicine, 3401 North Broad Street, Philadelphia, PA 19140, USA; asadjehangir@gmail.com

* Correspondence: henryp@temple.edu; Tel.: +1-215-764-2609

Received: 16 October 2019; Accepted: 15 November 2019; Published: 19 November 2019

\begin{abstract}
The symptoms of gastroparesis, such as nausea, vomiting, postprandial fullness, early satiety and abdominal pain, frequently impair the quality of life of the affected individuals. The diagnosis of gastroparesis is made after structural etiologies are ruled out and an assessment of gastric function shows delayed gastric emptying. The role of the delay in gastric emptying in the pathogenesis of symptoms of gastroparesis has been debated, with some studies suggesting an association between delayed gastric emptying and the upper gastrointestinal symptoms, while others do not. The recent literature supports the importance of using reliable methods to assess gastric emptying, as delay in gastric emptying measured on a reliable test (4-h scintigraphy or breath test) is associated with the severity of upper gastrointestinal symptoms. In addition to measuring total gastric emptying, evaluation of regional gastric retention in the proximal and distal stomach and whole gut transit to assess small intestinal and colonic transit may provide additional useful information in patients with more generalized symptoms of gastrointestinal dysmotility.
\end{abstract}

Keywords: gastroparesis; gastric emptying; scintigraphy

\section{Introduction}

Gastroparesis (Gp) is a symptomatic disorder of delayed gastric emptying in the absence of mechanical obstruction [1,2]. The pathophysiology of $\mathrm{Gp}$ has not been fully determined but appears to be secondary to abnormalities in functioning of several elements, including autonomic nervous system, smooth muscle cells, enteric neurons, and interstitial cells of Cajal [2-4]. Gp affects nearly $2 \%$ of the U.S. population [5].

The two most common subtypes of Gp are idiopathic Gp and diabetic Gp [6]. Delayed gastric emptying has been found to occur in up to $40 \%$ of patients with type 1 diabetes mellitus and $20 \%$ of patients with type 2 diabetes mellitus [3,7]. The third most common subtype is postsurgical Gp [6]. In the past, gastric ulcer resection surgery, particularly with vagotomy was the surgery most commonly associated with Gp [8]. Today, the more common surgical procedures associated with postsurgical $\mathrm{Gp}$ appear to be fundoplication and bariatric surgeries [6]. In atypical cases patients can develop Gp symptoms associated with connective tissue and neuromuscular diseases such as Scleroderma, Systemic Lupus Erythematosus, Ehlers Danlos Syndrome, Sjögren's Syndrome, Parkinson's disease, and Myasthenia Gravis [6,8].

\section{Symptoms of Gastroparesis}

Patients with gastroparesis typically report a variety of gastrointestinal (GI) symptoms including nausea, vomiting, early satiety, post-prandial fullness, and abdominal pain [6]. The symptoms of Gp may be indistinguishable from functional dyspepsia and chronic nausea and vomiting syndrome 
without assessment of gastric emptying [6]. The causes of abdominal pain in Gp patients can be multifactorial with somatic, visceral and neuropathic components [9]. A fourth of patients with Gp may also experience moderate to severe reflux symptoms [10]. Some patients with diabetes may present with worsening glucose control [11].

Patient Reported Outcomes (PROs) for Gp assess symptoms of Gp, as developed from patients with documented $\mathrm{Gp}$. Of the several questionnaires used to assess Gp symptoms, one of the most commonly used is the Patient Assessment of Gastrointestinal Symptoms (PAGI-SYM) questionnaire [12]. This validated questionnaire asks the patients to rate the severity of 24 common GI symptoms over the past two weeks [12]. The Gastroparesis Cardinal Symptom Index (GCSI) consists of three subscales of PAGI-SYM (nausea/vomiting subscale, postprandial fullness/early satiety subscale and bloating subscale) to measure important symptoms of Gp. The PAGI-SYM and GCSI use a 2-week recall of symptoms. To better capture ongoing symptoms of Gp, which could be either persistent or with periodic worsening and/or improvement [3], the Gastroparesis Cardinal Symptom Index-Daily Diary (GCSI-DD) has been developed [13]. This questionnaire grades the severity of nausea, early satiety, postprandial fullness and upper abdominal pain on a 0 (none), 1 (mild), 2 (moderate), 3 (severe), 4 (very severe) scale, and also records the number of episodes of vomiting to assess these symptoms over the past 24-h [13]. The GCSI-DD has excellent reliability and validity in assessing symptoms in patients with either idiopathic or diabetic Gp [14-16]. In patients with diabetic Gp, the Diabetic Gastroparesis Symptom Severity Diary (DGSSD) has been shown to be a reliable and valid tool to assess Gp symptoms [17]. DGSSD assesses the severity of nausea, vomiting, abdominal pain, early satiety, bloating and post-prandial fullness, and episodes of vomiting [17].

The symptoms of Gp can significantly impair the quality of life of the patients [18]. In a survey of 1423 patients with $\mathrm{Gp}$, the severities of nausea, abdominal pain and early satiety negatively correlated with patients' quality of life score [18]. The symptoms of Gp patients can also impose considerable burden on their caregivers [19]. The burden experiences by the caregivers of these patients correlates with severities of patients' symptoms and their healthcare utilization and negatively impacts the work productivity of these caregivers [19].

\section{Assessment of Gastric Emptying}

Gastric emptying is typically assessed using a radio-labelled meal on gastric emptying scintigraphy (GES). Wireless motility capsule (WMC) and gastric emptying breath testing (GEBT) offer radiation-free office-based assessment of gastric emptying. The use of ultrasonography and magnetic resonance imaging to measure gastric emptying is currently limited for research purposes (Table 1).

Table 1. Methods of assessing gastric emptying.

\begin{tabular}{|c|c|c|}
\hline $\begin{array}{l}\text { Methods to Assess } \\
\text { Gastric Emptying }\end{array}$ & Advantages & Disadvantages \\
\hline $\begin{array}{l}\text { Gastric Emptying } \\
\text { Scintigraphy }\end{array}$ & $\begin{array}{l}\text { - } \quad \text { Correlation with } \\
\text { symptom severity }{ }^{1} \\
\text { - } \quad \text { Low cost }\end{array}$ & Small radiation exposure \\
\hline $\begin{array}{l}\text { Gastric Emptying Breath } \\
\text { Testing }\end{array}$ & No radiation exposure & $\begin{array}{l}\text { - Interpretation difficult in emphysema, } \\
\text { liver cirrhosis, pancreatic insufficiency } \\
\text { and Celiac sprue }\end{array}$ \\
\hline $\begin{array}{l}\text { Wireless Motility } \\
\text { Capsule }\end{array}$ & $\begin{array}{ll}\text { - } & \text { No radiation exposure } \\
\text { - } & \text { Assessment of whole } \\
\text { gut transit }\end{array}$ & $\begin{array}{ll}\text { - } & \text { Capsule retention/equipment failure risk } \\
\text { - } & \text { Non-confirmatory in patients on PPIs } \\
\text { - } & \text { Contraindicated in ileus or gastric bezoar }\end{array}$ \\
\hline
\end{tabular}


Table 1. Cont.

\begin{tabular}{|c|c|c|}
\hline $\begin{array}{l}\text { Methods to Assess } \\
\text { Gastric Emptying }\end{array}$ & Advantages & Disadvantages \\
\hline Ultrasonography & No radiation exposure & $\begin{array}{ll}- & \text { Operator dependent } \\
- & \text { Only reliable for liquid emptying } \\
- & \text { Challenging in obese patients }\end{array}$ \\
\hline $\begin{array}{l}\text { Magnetic Resonance } \\
\text { Imaging }\end{array}$ & - $\quad$ No radiation exposure & $\begin{array}{ll}- & \text { Expensive } \\
- & \text { Done in supine position }\end{array}$ \\
\hline
\end{tabular}

${ }^{1}$ When assessed using standardized technique. ${ }^{2}$ Small risk (<1\%). Abbreviations: PPPs (Proton Pump Inhibitors).

\subsection{Gastric Emptying Scintigraphy}

There is much variability in the methodology in performing gastric emptying scintigraphy at different centers. Standardization of gastric emptying among different centers has been suggested using a four-hour imaging protocol with scans taken $0,1,2,4 \mathrm{~h}$ after ingestion of a radioactive Tc-99m labeled low-fat egg white with jam and two pieces of toast [20,21]. Patients should be instructed to stop medications that can affect GI motility (e.g., prokinetics, opioid analgesics, anti-cholinergic agents and glucagon-like peptide agonists) for $48-72 \mathrm{~h}$ prior to the study (or longer based on the pharmacokinetics of the medication). The GES test is performed after an overnight (at least $8 \mathrm{~h}$ ) fast. Diabetics should have their glucose checked at the beginning of the study, and appropriate treatment measures should be taken if hypoglycemia $(<70 \mathrm{mg} / \mathrm{dL})$ or hyperglycemia $(>250 \mathrm{mg} / \mathrm{dL})$ is detected. Gastric emptying is analyzed as the percent of radioactivity retained in the stomach over time using the geometric center of the decay-corrected anterior and posterior gastric counts for each time point. Gastric retention of Tc- $99 \mathrm{~m}>60 \%$ at $2 \mathrm{~h}$ and/or $>10 \%$ at $4 \mathrm{~h}$ is considered delayed gastric emptying of solids [21]. Assessing gastric emptying over $4 \mathrm{~h}$ helps in improved detection of patients with delayed gastric emptying [22]. Some authors proposed assessing gastric emptying using radiolabeled meal with higher caloric and fat content more typical of patients' diet to improve the sensitivity of the test [23,24]. Some patients may not be able to tolerate the solid meal conventionally used in GES and may benefit from assessment of gastric emptying using radiolabeled liquid nutrient meal, which has similar normal values comparable to the solid egg sandwich meal. Studies correlating gastric emptying of solids to non-nutrient liquids (water) have only found weak to moderate correlation between the two [25,26]. Gastric emptying of liquids has a lower sensitivity and is generally used in assessment of dumping syndrome and assessment of post-surgical gastric changes [27].

In patients with symptoms suggestive of Gp, the GES results are relatively reproducible. However, in $30 \%$ of the patients, gastric emptying results may change over time. Hence, a diagnosis of Gp based on one GES study may sometimes be inaccurate [28]. This is particularly true when referred a patient who had previously undergone a gastric emptying test using suboptimal methods, such as imaging over only one hour. Relatively high interindividual and intraindividual variability in gastric emptying rates constitutes a limitation of gastric motor testing [3].

Normal gastric emptying results from coordinated activity between fundus, antrum, pylorus and duodenum [27]. Gastric emptying scintigraphy can be used to determine intra-gastric meal distribution in the fundus and antrum for regional assessment of gastric function. This may be helpful to explain the pathophysiology of dyspeptic symptoms, particularly in patients with normal total gastric emptying [27]. Early satiety has been associated with rapid proximal gastric emptying, suggesting impaired accommodation [29].

\subsection{Gastric Emptying Breath Testing}

Gastric Emptying Breath Testing is an office-based test that measures labeled nonradioactive 13-CO2 in exhaled breath samples after ingestion of a 13-C02 labeled meal. Breath samples are obtained periodically over several hours. The exhaled 13-C02 represents the combined processes of 
gastric emptying, duodenal absorption, hepatic metabolism, and pulmonary excretion, where gastric emptying is the rate limiting step [30]. Findings are generally reproducible and correlate well with results of GES [31,32]. GEBT has been used clinically in Europe for years, whereas in the U.S., breath test for Gp had been generally used for research studies but is now approved by the Food and Drug Administration for use in clinical practice [33].

\subsection{Wireless Motility Capsule}

Wireless motility capsule (WMC) is an office-based radiation-free test that helps in the assessment of whole gut transit by quantifying luminal $\mathrm{pH}$ (range 0.5-9.0), pressure (range 0-350 $\mathrm{mmHg}$ ) and temperature (range $25-49^{\circ} \mathrm{C}$ ) [3,34]. The ingestible WMC empties with phase III migrating motor complex. Initially after capsule ingestion, the acidic gastric secretions are recorded, which can be temporally buffered by the nutrient meal consumed prior to capsule ingestion. Gastric emptying is manifested by a sharp increase in $\mathrm{pH}$ representing the capsule passing from the acidic stomach to the alkaline small intestine [35]. In a validation study comparing gastric emptying times on WMC and gastric emptying scintigraphy, there was a significant correlation between the two [35]. The normal transit time for the stomach on WMC is $2-5 \mathrm{~h}$, for small bowel $2-6 \mathrm{~h}$, and for colon 10-59 $\mathrm{h}$ [34]. Using a 5-h cutoff for gastric emptying, the capsule discriminates between normal or delayed gastric emptying with a sensitivity of 0.65 and a specificity of 0.87 [35].

The wireless motility capsule assesses whole gut transit. Colonic transit abnormalities have been reported in $18 \%$ of patients with Gp, possibly suggesting a more diffuse GI motility disorder contributing to symptom presentation [36]. In a comparative, prospective cohort study across 10 centers, 154 patients (53 diabetics, 114 non-diabetics) simultaneously underwent GES and WMC assessments. Interestingly, WMC was more sensitive in identifying patients with delayed gastric emptying, whereas GES was more sensitive in identifying patients with rapid gastric emptying [37].

Wireless motility capsule may be difficult to swallow for some patients due to its size (length $26.8 \mathrm{~mm}$, diameter $11.7 \mathrm{~mm}$ ). The use of proton pump inhibitors may reduce the $\mathrm{pH}$ change at gastric emptying. If the $\mathrm{pH}$ changes are non-confirmatory, contractility patterns of stomach and small bowel may help in determining the transit times. There is a small $(0.3 \%)$ risk of prolonged capsule retention in patients undergoing wireless motility capsule testing [38]. In patients reporting symptoms of capsule retention such as abdominal pain, nausea and/or vomiting, radiographic imaging can be performed to confirm capsule retention [37]. Endoscopy may be needed for retrieval of capsules that do not empty from the stomach.

\subsection{Ultrasonography}

Ultrasonography can help in the assessment of gastric emptying and contractility, gastric accommodation, and transpyloric flow of liquid gastric contents [27]. However, the ultrasonographic assessment of gastric motility is operator-dependent, may be difficult to perform in obese patients, and has proven reliability only for assessment of liquid gastric emptying. Ultrasonography is typically used to measure gastric emptying in research studies only [27]. 3-D ultrasonography may provide a more accurate assessment of gastric volumes and hence the gastric emptying [39].

\subsection{Gastric Magnetic Resonance Imaging}

Gastric magnetic resonance imaging (MRI) can help assess gastric emptying and accommodation using the spin-echo technique with T1 weighting imaging [40]. Gastric MRI can distinguish between gastric meal volume and total gastric volume, which can be used to determine gastric secretory rates [27]. The use of MRI also helps separately measure gastric emptying of fat and liquids. Gastric emptying assessed by MRI avoids radiation exposure and correlates with gastric retention measured on gastric emptying scintigraphy. However, the significant cost of the MRI currently limits its use to research purposes [27]. 


\section{Role of Gastric Emptying in Symptoms of Gastroparesis}

The role of gastric emptying in the pathogenesis of symptoms of suggestive of gastroparesis has been controversial, with some studies suggesting an association between delayed gastric emptying and upper symptoms (Table 2) [41-58], while others not demonstrating an association (Table 3) [59-64]. A large single-center study with 1499 patients undergoing GES for clinical evaluation found $629(42 \%)$ patients to have delayed $4 \mathrm{~h}$ gastric emptying [65]. In this study, the gastric retention at 4-h had weak but statistically significant $(p<0.01)$ correlations with important symptoms of Gp including early satiety $(r=0.17)$, vomiting $(r=0.14)$, post-prandial fullness $(r=0.12)$ and loss of appetite $(r=0.12)$ [65]. A study by the National Institute of Diabetes and Digestive and Kidney Diseases -Gastroparesis Consortium found that severities of early satiety and post-prandial fullness are associated with gastric emptying [65]. A recent meta-analysis of literature from 2007-2017 using 25 studies (total of 6287 patients) found that studies using optimal gastric emptying assessment methodologies in patients with upper GI symptoms found significant associations of gastric emptying with severities of nausea (OR 1.6), vomiting (OR 2.0), abdominal pain (OR 1.5), and early satiety/fullness (OR 1.8) [66].

Table 2. Studies suggestive of correlation of gastric emptying and upper gastrointestinal symptoms.

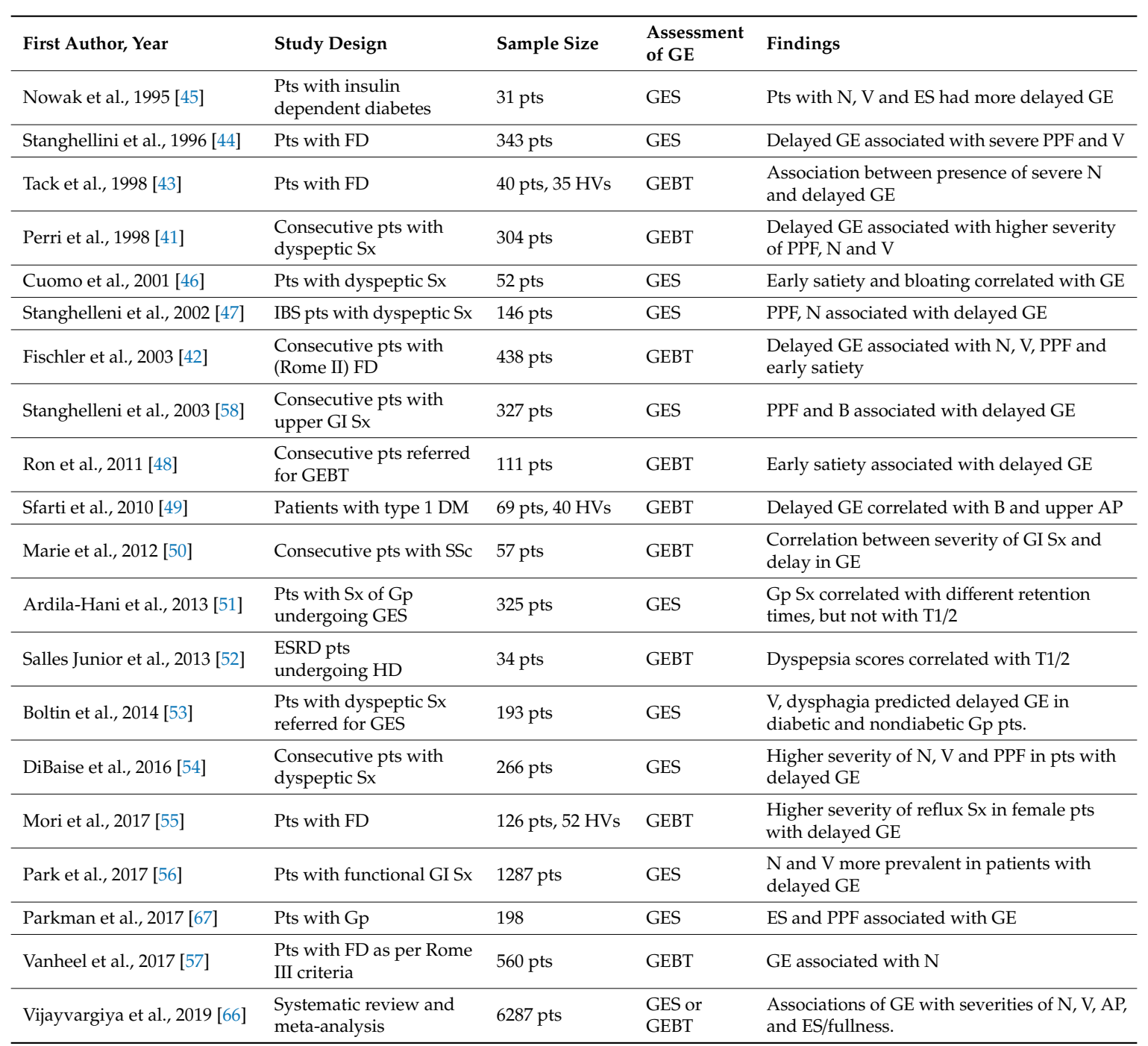

Abbreviations: AP (Abdominal Pain), B (Bloating), DM (Diabetes Mellitus), ES (Early Satiety), ESRD (End Stage Renal Disease), FD (Functional Dyspepsia), GEBT (Gastric Emptying Breath Test), Gastric Emptying (GE), GES (Gastric Emptying Scintigraphy), GI (Gastrointestinal), Gp (Gastroparesis), HD (Hemodialysis), HVs (Healthy Volunteers), IBS (Irritable Bowel Syndrome), N (Nausea), PPF (Post-prandial fullness), Pts (Patients), SSc (Systemic Sclerosis), $\mathrm{Sx}$ (Symptoms), $\mathrm{T}_{1 / 2}$ (time to empty half of gastric contents), $\mathrm{V}$ (Vomiting). 
Table 3. Studies not finding an association between gastric emptying and upper gastrointestinal symptoms.

\begin{tabular}{|c|c|c|c|c|}
\hline First Author, Year & Study Design & Sample Size & $\begin{array}{l}\text { Assessment of Gastric } \\
\text { Emptying }\end{array}$ & Conclusions \\
\hline Talley et al., 2001 [59] & Pts with dyspeptic Sx & 708 pts & GEBT & $\begin{array}{l}\text { No correlation between } T_{1 / 2} \\
\text { and severity of } S x\end{array}$ \\
\hline Talley et al., 2006 [62] & Pts with (Rome II) FD & 864 pts & GES & $\begin{array}{l}\text { No association of delayed } \\
\text { GE with AP, ES, N or B; only } \\
\text { weak association with PPF }\end{array}$ \\
\hline $\begin{array}{l}\text { Karamanolis et al., } \\
2007 \text { [64] }\end{array}$ & Pts with idiopathic Gp & $58 \mathrm{pts}$ & GES & $\begin{array}{l}\text { Overall Sx severity did not } \\
\text { correlate with GE }\end{array}$ \\
\hline Cherian et al., 2010 [63] & Pts with Sx of Gp & $68 \mathrm{pts}$ & GES & $\begin{array}{l}\text { AP severity did not correlate } \\
\text { with GE }\end{array}$ \\
\hline Pasricha et al., 2011 [60] & $\begin{array}{l}\text { Pts with chronic } \mathrm{N} \text { and } \\
\mathrm{V}\end{array}$ & 425 pts & GES & $\begin{array}{l}\text { Total Gp cardinal Sx index } \\
\text { scores did not correlate with } \\
\text { GE. Sx severities similar } \\
\text { between pts with delayed } \\
\text { and normal GE. }\end{array}$ \\
\hline Janssen et al., 2013 [68] & $\begin{array}{l}\text { Meta-regression } \\
\text { analysis }\end{array}$ & $480 \mathrm{pts}$ & $\begin{array}{l}\text { GES, GEBT, } \\
\text { ultrasound, } \\
\text { radiopaque markers }\end{array}$ & $\begin{array}{l}\text { No relationship between } \\
\text { improvement of Sx and GE } \\
\text { using different drugs for Gp. }\end{array}$ \\
\hline Anudeep et al., 2016 [61] & $\begin{array}{l}\text { Pts with T2DM for } \geq 5 \\
\text { years) }\end{array}$ & $\begin{array}{l}140 \text { pts, } 30 \\
\text { HVs }\end{array}$ & GES & $\begin{array}{l}\text { No correlation between Sx of } \\
\text { Gp and delayed GE. }\end{array}$ \\
\hline Jehangir et al., 2018 [6] & $\begin{array}{l}\text { Consecutive pts with } \\
\text { Sx of Gp }\end{array}$ & 357 pts & GES & $\begin{array}{l}\text { Symptom severities similar } \\
\text { between patients with } \\
\text { delayed and normal GE. }\end{array}$ \\
\hline
\end{tabular}

Gp patients often experience reflux symptoms, with the recent literature using $4 \mathrm{~h}$ GES suggesting an overlap in $8 \%-20 \%$ of patients with Gp and gastroesophageal reflux disease [69]. In a study on 432 patients with delayed gastric emptying on 4-h GES, the severity of reflux symptoms in Gp patients had a moderate to strong correlation with the typical symptoms of $\mathrm{Gp}$, but a weak correlation with the 4-h gastric retention $(r=0.11, p=0.02)$ [10].

The National Institute of Diabetes and Digestive and Kidney Diseases - Gastroparesis Consortium studies on patients with symptoms of Gp found a number of patients with symptoms of Gp but normal gastric emptying, termed chronic unexplained nausea and vomiting (CUNV) [60]. Over a third of patients with symptoms of Gp have normal total gastric emptying suggesting that factors, in addition to slow gastric emptying, also appear to be important in the pathogenesis of Gp symptoms [6]. Assessment of regional gastric retention and fundic accommodation during GES may provide additional information regarding the pathogenesis of dyspeptic symptoms. Studies in patients with functional dyspepsia have shown that a fourth of patients have delayed gastric emptying only, a fourth have impaired fundic accommodation only, a fourth have both delayed gastric emptying and impaired fundic accommodation, and a fourth have normal gastric emptying and fundic accommodation [56]. Using intragastric meal distribution during gastric emptying scintigraphy, proximal gastric retention has been associated with symptoms of early satiety, loss of appetite and stomach fullness, whereas combined proximal and distal retention has been associated with symptom of nausea $[29,64]$.

Patients with symptoms of Gp can have motility disturbances in other segments of the GI tract. Small bowel manometry may help confirm a diagnosis of GI dysmotility in patients with normal or borderline gastric emptying [27]. A study by Barshop et al. found a moderate correlation between duodenal contractility on WMC and severity of Gp symptoms [70]. In patients with symptoms of Gp, small intestinal dysmotility was found to be more prevalent than delayed gastric emptying and the presence of small intestinal dysmotility was associated with more severe symptoms of Gp [71]. Studies using a wireless motility capsule have also suggested that patients with symptoms of Gp but normal 
gastric emptying can have small intestinal or colonic transit and contractile abnormalities [37]. Hence, assessment of the motility of the entire GI tract may be important with functional GI disorders with more generalized symptoms [37].

Many of the currently available pharmacological treatments for Gp are aimed to both improve symptoms and gastric emptying - these are the prokinetic agents. An analysis by Janssen et al. assessing studies on various pharmacological treatments for Gp did not find a significant correlation between improvement in symptom severity and gastric emptying [68]. However, a recent meta-analysis showed that when optimal gastric emptying tests are used ( $4 \mathrm{~h}$ gastric emptying scintigraphy or breath test), there is a significant relationship between improvement in gastric emptying and improvement in GI symptoms using prokinetics agents $(p=0.02)$ [72]. Gastric electric stimulation has been shown to improve symptoms in some patients with Gp symptoms refractory to medical management, without necessarily improving gastric emptying, suggesting that modification of gastric sensation to distension may also be important in improvement of symptoms of $\mathrm{Gp}$ [73]. In our opinion, a demonstration of a delay in gastric emptying to diagnose patients with $\mathrm{Gp}$ is needed prior to undertaking therapies that pose risk to patients and/or the treatment's sole mechanism of action is to improve gastric emptying; these treatments include medical therapy (metoclopramide, domperidone, erythromycin), botulinum toxin injection in the pylorus, gastric electric stimulation, and pyloromyotomy.

Amongst patients with symptoms suggestive of $\mathrm{Gp}$, a considerable proportion have normal gastric emptying [6]. The majority of these patients with symptoms but normal gastric emptying are diagnosed with the Rome diagnoses of functional dyspepsia or chronic nausea and vomiting syndrome, or the GpCRC term of Chronic Unexplained Nausea and Vomiting [6,61]. Assessment of gastric emptying may have important therapeutic implications in patients with symptoms of dyspepsia. Patients with dyspeptic symptoms with normal gastric emptying symptoms report significant improvement of symptoms with neuromodulators like amitriptyline, but patients with delayed gastric emptying do not [74]. In a randomized, placebo-controlled trial, the use of nortriptyline did not show an improvement in symptoms in patients with idiopathic Gp [75]. Some of the patients with normal global gastric emptying may have other causes of their GI symptoms including impaired gastric accommodation, extra-gastric motility disturbance or hypersensitivity to gastric retention $[37,56,76]$. Treatment of these may help improve patient's symptoms. A thorough assessment of the etiology of symptoms in patients with symptoms suggestive of $\mathrm{Gp}$ and tailoring the treatments to the underlying cause may improve their outcomes.

Various surgeries may also negatively impact gastric emptying post-surgically at variable rates. Pancreatoduodenectomy is particular is associated with a high risk of postsurgical Gp. In a study on 73 patients undergoing pancreatoduodenectomy, 27 (36.9\%) developed clinically significant delayed gastric emptying post-operatively [77]. Postsurgical Gp may also be seen after other surgeries, including esophagectomy (12\%), distal gastrectomy with Roux-en-Y reconstruction (9\%), lung transplantation $(6 \%)$, paraesophageal hernia repair $(4.4 \%)$ and fundoplication $(3.8 \%)$ [78-80]. The presence of visceral obesity predicts the development of postsurgical $\mathrm{Gp}$ in patients undergoing distal gastrectomy for gastric cancer [81]. Postsurgical delay in gastric emptying may result in a higher severity of gastrointestinal symptoms. In patients undergoing pancreatoduodenectomy, postsurgical delay in gastric emptying is associated with worse gastrointestinal quality of life [77].

\section{Conclusions}

Gastric emptying is important in the pathogenesis of symptoms of gastroparesis. However, there can also be other mechanisms for the symptoms, including impaired gastric accommodation, hypersensitivity, and extragastric transit abnormalities. Gastric emptying is best determined with a reliable test using a standardized protocol such as gastric emptying scintigraphy, gastric emptying breath test, or wireless motility capsule. Symptoms that appear to be related to delayed gastric emptying include nausea, vomiting, early satiety and postprandial fullness, but not symptoms of abdominal pain and bloating. In addition to measuring global gastric emptying, evaluation of regional gastric 
retention and whole gut transit to rule out extra-gastric motility disturbance may provide additional useful information in patients with more generalized symptoms of gastrointestinal dysmotility.

Author Contributions: A.J. writing—original draft preparation, H.P.P., writing—critical revision of the manuscript for important intellectual content.

Conflicts of Interest: The authors declare no conflict of interest.

\section{References}

1. Parkman, H.P.; Hasler, W.L.; Fisher, R.S. AmericanGastroenterological Association. American Gastroenterological Association medical position statement: Diagnosis and treatment of gastroparesis. Gastroenterology 2004, 127, 1589-1591. [CrossRef] [PubMed]

2. Camilleri, M.; Parkman, H.P.; Shafi, M.A.; Abell, T.L.; Gerson, L. American College of Gastroenterology. Clinical guideline: Management of gastroparesis. Am. J. Gastroenterol. 2013, 108, 18-37. [CrossRef] [PubMed]

3. Hasler, W.L. Gastroparesis: Pathogenesis, diagnosis and management. Nat. Rev. Gastroenterol. Hepatol. 2011, 8, 438-453. [CrossRef] [PubMed]

4. Parkman, H.P.; Yates, K.; Hasler, W.L.; Nguyen, L.; Pasricha, P.J.; Snape, W.J.; Farrugia, G.; Koch, K.L.; Abell, T.L.; McCallum, R.W.; et al. Clinical features of idiopathic gastroparesis vary with sex, body mass, symptom onset, delay in gastric emptying, and gastroparesis severity. Gastroenterology 2011, 140, 101-115. [CrossRef] [PubMed]

5. Rey, E.; Choung, R.S.; Schleck, C.D.; Zinsmeister, A.R.; Talley, N.J.; Locke, G.R. Prevalence of hidden gastroparesis in the community: The gastroparesis "iceberg". J. Neurogastroenterol. Motil. 2012, 18, 34-42. [CrossRef] [PubMed]

6. Jehangir, A.; Parkman, H.P.; Rome, I.V. Diagnostic Questionnaire Complements Patient Assessment of Gastrointestinal Symptoms for Patients with Gastroparesis Symptoms. Dig. Dis. Sci. 2018, 63, 2231-2243. [CrossRef] [PubMed]

7. Jones, K.L.; Russo, A.; Stevens, J.E.; Wishart, J.M.; Berry, M.K.; Horowitz, M. Predictors of delayed gastric emptying in diabetes. Diabetes Care 2001, 24, 1264-1269. [CrossRef]

8. Quigley, E.M.M. Other forms of gastroparesis: Postsurgical, Parkinson, other neurologic diseases, connective tissue disorders. Gastroenterol. Clin. N. Am. 2015, 44, 69-81. [CrossRef]

9. Jehangir, A.; Abdallah, R.T.; Parkman, H.P. Characterizing Abdominal Pain in Patients with Gastroparesis Into Neuropathic and Nociceptive Components. J. Clin. Gastroenterol. 2019, 53, 427-433. [CrossRef]

10. Jehangir, A.; Parkman, H.P. Reflux Symptoms in Gastroparesis: Correlation with Gastroparesis Symptoms, Gastric Emptying, and Esophageal Function Testing. J. Clin. Gastroenterol. 2019. [CrossRef]

11. Setty, S.G.; Kong, M.-F. Intractable nausea and vomiting associated with poor glycaemic control in a patient with type 1 diabetes. BMJ 2016, 354, 4197. [CrossRef] [PubMed]

12. Rentz, A.M.; Kahrilas, P.; Stanghellini, V.; Tack, J.; Talley, N.J.; Trudeau, E.; Dubois, D.; Revicki, D.A. Development and psychometric evaluation of the patient assessment of upper gastrointestinal symptom severity index (PAGI-SYM) in patients with upper gastrointestinal disorders. Qual. Life Res. 2004, 13, 1737-1749. [CrossRef] [PubMed]

13. Revicki, D.A.; Camilleri, M.; Kuo, B.; Norton, N.J.; Murray, L.; Palsgrove, A.; Parkman, H.P. Development and content validity of a gastroparesis cardinal symptom index daily diary. Aliment. Pharmacol. Ther. 2009, 30, 670-680. [CrossRef] [PubMed]

14. Revicki, D.A.; Speck, R.M.; Lavoie, S.; Puelles, J.; Kuo, B.; Camilleri, M.; Almansa, C.; Parkman, H.P. The American neurogastroenterology and motility society gastroparesis cardinal symptom index-daily diary (ANMS GCSI-DD): Psychometric evaluation in patients with idiopathic or diabetic gastroparesis. Neurogastroenterol. Motil. 2019, 31, 13553. [CrossRef] [PubMed]

15. Revicki, D.A.; Lavoie, S.; Speck, R.M.; Puelles, J.; Kuo, B.; Camilleri, M.; Almansa, C.; Parkman, H.P. The content validity of the ANMS GCSI-DD in patients with idiopathic or diabetic gastroparesis. J. Patient Rep. Outcomes 2018, 2, 61. [CrossRef] [PubMed]

16. Revicki, D.A.; Camilleri, M.; Kuo, B.; Szarka, L.A.; McCormack, J.; Parkman, H.P. Evaluating symptom outcomes in gastroparesis clinical trials: Validity and responsiveness of the Gastroparesis Cardinal Symptom Index-Daily Diary (GCSI-DD). Neurogastroenterol. Motil. 2012, 24, 456-463. [CrossRef] [PubMed] 
17. Fehnel, S.; Fiedorek, F.T.; Nelson, L.; DiBenedetti, D.; Spence, S.; Carson, R.T. Development and psychometric evaluation of the Diabetic Gastroparesis Symptom Severity Diary. Clin. Exp. Gastroenterol. 2019, 12, 93-103. [CrossRef]

18. Yu, D.; Ramsey, F.V.; Norton, W.F.; Norton, N.; Schneck, S.; Gaetano, T.; Parkman, H.P. The Burdens, Concerns, and Quality of Life of Patients with Gastroparesis. Dig. Dis. Sci. 2017, 62, 879-893. [CrossRef]

19. Jehangir, A.; Collier, A.; Shakhatreh, M.; Malik, Z.; Parkman, H.P. Caregiver Burden in Gastroparesis and GERD: Correlation with Disease Severity, Healthcare Utilization and Work Productivity. Dig. Dis. Sci. 2019, 64, 3451-3492. [CrossRef]

20. Abell, T.L.; Camilleri, M.; Donohoe, K.; Hasler, W.L.; Lin, H.C.; Maurer, A.H.; McCallum, R.W.; Nowak, T.; Nusynowitz, M.L.; Parkman, H.P.; et al. Consensus recommendations for gastric emptying scintigraphy: A joint report of the American Neurogastroenterology and Motility Society and the Society of Nuclear Medicine. Am. J. Gastroenterol. 2008, 103, 753-763. [CrossRef]

21. Tougas, G.; Eaker, E.Y.; Abell, T.L.; Abrahamsson, H.; Boivin, M.; Chen, J.; Hocking, M.P.; Quigley, E.M.; Koch, K.L.; Tokayer, A.Z.; et al. Assessment of gastric emptying using a low fat meal: Establishment of international control values. Am. J. Gastroenterol. 2000, 95, 1456-1462. [CrossRef] [PubMed]

22. Guo, J.P.; Maurer, A.H.; Fisher, R.S.; Parkman, H.P. Extending gastric emptying scintigraphy from two to four hours detects more patients with gastroparesis. Dig. Dis. Sci. 2001, 46, 24-29. [CrossRef] [PubMed]

23. Camilleri, M.; Shin, A. Novel and validated approaches for gastric emptying scintigraphy in patients with suspected gastroparesis. Dig. Dis. Sci. 2013, 58, 1813-1815. [CrossRef] [PubMed]

24. Camilleri, M.; Iturrino, J.; Bharucha, A.E.; Burton, D.; Shin, A.; Jeong, I.D.; Zinsmeister, A.R. Performance characteristics of scintigraphic measurement of gastric emptying of solids in healthy participants. Neurogastroenterol. Motil. 2012, 24, 1076-e562. [CrossRef]

25. Sachdeva, P.; Kantor, S.; Knight, L.C.; Maurer, A.H.; Fisher, R.S.; Parkman, H.P. Use of a high caloric liquid meal as an alternative to a solid meal for gastric emptying scintigraphy. Dig. Dis. Sci. 2013, 58, 2001-2006. [CrossRef]

26. Jones, K.L.; Horowitz, M.; Wishart, M.J.; Maddox, A.F.; Harding, P.E.; Chatterton, B.E. Relationships between gastric emptying, intragastric meal distribution and blood glucose concentrations in diabetes mellitus. J. Nucl. Med. 1995, 36, 2220-2228.

27. Parkman, H.P.; Jones, M.P. Tests of gastric neuromuscular function. Gastroenterology 2009, 136, $1526-1543$. [CrossRef]

28. Desai, A.; O'Connor, M.; Neja, B.; Delaney, K.; Camilleri, M.; Zinsmeister, A.R.; Bharucha, A.E. Reproducibility of gastric emptying assessed with scintigraphy in patients with upper GI symptoms. Neurogastroenterol. Motil. 2018, 30, 13365. [CrossRef]

29. Orthey, P.; Yu, D.; VanNatta, M.L.; Ramsey, F.V.; Diaz, J.R.; Bennett, P.A.; Iagaru, A.H.; Fragomeni, R.S.; McCallum, R.W.; Sarosiek, I.; et al. Intragastric Meal Distribution During Gastric Emptying Scintigraphy for Assessment of Fundic Accommodation: Correlation with Symptoms of Gastroparesis. J. Nucl. Med. 2018, 59, 691-697. [CrossRef]

30. Parkman, H.P. Assessment of gastric emptying and small-bowel motility: Scintigraphy, breath tests, manometry, and SmartPill. Gastrointest. Endosc. Clin. N. Am. 2009, 19, 49-55. [CrossRef]

31. Ghoos, Y.F.; Maes, B.D.; Geypens, B.J.; Mys, G.; Hiele, M.I.; Rutgeerts, P.J.; Vantrappen, G. Measurement of gastric emptying rate of solids by means of a carbon-labeled octanoic acid breath test. Gastroenterology 1993, 104, 1640-1647. [CrossRef]

32. Choi, M.G.; Camilleri, M.; Burton, D.D.; Zinsmeister, A.R.; Forstrom, L.A.; Nair, K.S. Reproducibility and simplification of 13C-octanoic acid breath test for gastric emptying of solids. Am. J. Gastroenterol. 1998, 93, 92-98. [CrossRef] [PubMed]

33. Szarka, L.A.; Camilleri, M.; Vella, A.; Burton, D.; Baxter, K.; Simonson, J.; Zinsmeister, A.R. A stable isotope breath test with a standard meal for abnormal gastric emptying of solids in the clinic and in research. Clin. Gastroenterol. Hepatol. 2008, 6, 635-643. [CrossRef] [PubMed]

34. Lee, Y.Y.; Erdogan, A.; Rao, S.S.C. How to assess regional and whole gut transit time with wireless motility capsule. J. Neurogastroenterol. Motil. 2014, 20, 265-270. [CrossRef]

35. Kuo, B.; McCallum, R.W.; Koch, K.L.; Sitrin, M.D.; Wo, J.M.; Chey, W.D.; Hasler, W.L.; Lackner, J.M.; Katz, L.A.; Semler, J.R.; et al. Comparison of gastric emptying of a nondigestible capsule to a radio-labelled meal in healthy and gastroparetic subjects. Aliment. Pharmacol. Ther. 2008, 27, 186-196. [CrossRef] 
36. Sarosiek, I.; Selover, K.H.; Katz, L.A.; Semler, J.R.; Wilding, G.E.; Lackner, J.M.; Sitrin, M.D.; Kuo, B.; Chey, W.D.; Hasler, W.L.; et al. The assessment of regional gut transit times in healthy controls and patients with gastroparesis using wireless motility technology. Aliment. Pharmacol. Ther. 2010, 31, 313-322. [CrossRef]

37. Lee, A.A.; Rao, S.; Nguyen, L.A.; Moshiree, B.; Sarosiek, I.; Schulman, M.I.; Wo, J.M.; Parkman, H.P.; Wilding, G.E.; McCallum, R.W.; et al. Validation of Diagnostic and Performance Characteristics of the Wireless Motility Capsule in Patients With Suspected Gastroparesis. Clin. Gastroenterol. Hepatol. 2019, 17, 1770-1779. [CrossRef]

38. Rao, S.S.C.; Camilleri, M.; Hasler, W.L.; Maurer, A.H.; Parkman, H.P.; Saad, R.; Scott, M.S.; Simren, M.; Soffer, E.; Szarka, L. Evaluation of gastrointestinal transit in clinical practice: Position paper of the American and European Neurogastroenterology and Motility Societies. Neurogastroenterol. Motil. 2011, 23, 8-23. [CrossRef]

39. Gentilcore, D.; Hausken, T.; Horowitz, M.; Jones, K.L. Measurements of gastric emptying of low- and high-nutrient liquids using 3D ultrasonography and scintigraphy in healthy subjects. Neurogastroenterol. Motil. 2006, 18, 1062-1068. [CrossRef]

40. Kim, D.Y.; Myung, S.J.; Camilleri, M. Novel testing of human gastric motor and sensory functions: Rationale, methods, and potential applications in clinical practice. Am. J. Gastroenterol. 2000, 95, 3365-3373. [CrossRef]

41. Perri, F.; Clemente, R.; Festa, V.; Annese, V.; Quitadamo, M.; Rutgeerts, P.; Andriulli, A. Patterns of symptoms in functional dyspepsia: Role of Helicobacter pylori infection and delayed gastric emptying. Am. J. Gastroenterol. 1998, 93, 2082-2088. [CrossRef] [PubMed]

42. Fischler, B.; Tack, J.; De Gucht, V.; Shkedy, Z.I.; Persoons, P.; Broekaert, D.; Molenberghs, G.; Janssens, J. Heterogeneity of symptom pattern, psychosocial factors, and pathophysiological mechanisms in severe functional dyspepsia. Gastroenterology 2003, 124, 903-910. [CrossRef] [PubMed]

43. Tack, J.; Piessevaux, H.; Coulie, B.; Caenepeel, P.; Janssens, J. Role of impaired gastric accommodation to a meal in functional dyspepsia. Gastroenterology 1998, 115, 1346-1352. [CrossRef]

44. Stanghellini, V.; Tosetti, C.; Paternico, A.; Barbara, G.; Morselli-Labate, A.M.; Monetti, N.; Marengo, M.; Corinaldesi, R. Risk indicators of delayed gastric emptying of solids in patients with functional dyspepsia. Gastroenterology 1996, 110, 1036-1042. [CrossRef] [PubMed]

45. Nowak, T.V.; Johnson, C.P.; Kalbfleisch, J.H.; Roza, A.M.; Wood, C.M.; Weisbruch, J.P.; Soergel, K.H. Highly variable gastric emptying in patients with insulin dependent diabetes mellitus. Gut 1995, 37, 23-29. [CrossRef] [PubMed]

46. Cuomo, R.; Sarnelli, G.; Grasso, R.; Bruzzese, D.; Pumpo, R.; Salomone, M.; Nicolai, E.; Tack, J.; Budillon, G. Functional dyspepsia symptoms, gastric emptying and satiety provocative test: Analysis of relationships. Scand. J. Gastroenterol. 2001, 36, 1030-1036. [CrossRef] [PubMed]

47. Stanghellini, V.; Tosetti, C.; Barbara, G.; De Giorgio, R.; Cogliandro, L.; Cogliandro, R.; Corinaldesi, R. Dyspeptic symptoms and gastric emptying in the irritable bowel syndrome. Am. J. Gastroenterol. 2002, 97, 2738-2743. [CrossRef]

48. Ron, Y.; Sperber, A.D.; Levine, A.; Shevah, O.; Dickman, R.; Avni, Y.; Shirin, H. Early satiety is the only patient-reported symptom associated with delayed gastric emptying, as assessed by breath-test. J. Neurogastroenterol. Motil. 2011, 17, 61-66. [CrossRef]

49. Sfarti, C.; Trifan, A.; Hutanasu, C.; Cojocariu, C.; Singeap, A.-M.; Stanciu, C. Prevalence of gastroparesis in type 1 diabetes mellitus and its relationship to dyspeptic symptoms. J. Gastrointest. Liver Dis. 2010, 19, 279-284.

50. Marie, I.; Gourcerol, G.; Leroi, A.-M.; Ménard, J.-F.; Levesque, H.; Ducrotté, P. Delayed gastric emptying determined using the 13C-octanoic acid breath test in patients with systemic sclerosis. Arthritis Rheum. 2012, 64, 2346-2355. [CrossRef]

51. Ardila-Hani, A.; Arabyan, M.; Waxman, A.; Ih, G.; Berel, D.; Pimentel, M.; Conklin, J.; Soffer, E.E. Severity of dyspeptic symptoms correlates with delayed and early variables of gastric emptying. Dig. Dis. Sci. 2013, 58, 478-487. [CrossRef] [PubMed]

52. Junior, L.D.S.; Santos, P.R.; dos Santos, A.A.; de Souza, M.H.L.P. Dyspepsia and gastric emptying in end-stage renal disease patients on hemodialysis. BMC Nephrol. 2013, 14, 275. [CrossRef]

53. Boltin, D.; Zvidi, I.; Steinmetz, A.; Bernstine, H.; Groshar, D.; Nardi, Y.; Boaz, M.; Niv, Y.; Dickman, R. Vomiting and dysphagia predict delayed gastric emptying in diabetic and nondiabetic subjects. J. Diabetes Res. 2014, 2014, 294032. [CrossRef] [PubMed] 
54. DiBaise, J.K.; Patel, N.; Noelting, J.; Dueck, A.C.; Roarke, M.; Crowell, M.D. The relationship among gastroparetic symptoms, quality of life, and gastric emptying in patients referred for gastric emptying testing. Neurogastroenterol. Motil. 2016, 28, 234-242. [CrossRef]

55. Mori, H.; Suzuki, H.; Matsuzaki, J.; Taniguchi, K.; Shimizu, T.; Yamane, T.; Masaoka, T.; Kanai, T. Gender Difference of Gastric Emptying in Healthy Volunteers and Patients with Functional Dyspepsia. Digestion 2017, 95, 72-78. [CrossRef]

56. Park, S.-Y.; Acosta, A.; Camilleri, M.; Burton, D.; Harmsen, W.S.; Fox, J.; Szarka, L.A. Gastric Motor Dysfunction in Patients with Functional Gastroduodenal Symptoms. Am. J. Gastroenterol. 2017, 112, 1689-1699. [CrossRef]

57. Vanheel, H.; Carbone, F.; Valvekens, L.; Simren, M.; Tornblom, H.; Vanuytsel, T.; Van Oudenhove, L.; Tack, J. Pathophysiological Abnormalities in Functional Dyspepsia Subgroups According to the Rome III Criteria. Am. J. Gastroenterol. 2017, 112, 132-140. [CrossRef]

58. Stanghellini, V.; Tosetti, C.; Horowitz, M.; De Giorgio, R.; Barbara, G.; Cogliandro, R.; Cogliandro, L.; Corinaldesi, R. Predictors of gastroparesis in out-patients with secondary and idiopathic upper gastrointestinal symptoms. Dig Liver Dis. 2003, 35, 389-396. [CrossRef]

59. Talley, N.J.; Verlinden, M.; Jones, M. Can symptoms discriminate among those with delayed or normal gastric emptying in dysmotility-like dyspepsia? Am. J. Gastroenterol. 2001, 96, 1422-1428. [CrossRef]

60. Pasricha, P.J.; Colvin, R.; Yates, K.; Hasler, W.L.; Abell, T.L.; Unalp-Arida, A.; Nguyen, L.; Farrugia, G.; Koch, K.L.; Parkman, H.P.; et al. Characteristics of patients with chronic unexplained nausea and vomiting and normal gastric emptying. Clin. Gastroenterol. Hepatol. 2011, 9, 567-576. [CrossRef]

61. Anudeep, V.; Vinod, K.V.; Pandit, N.; Sharma, V.K.; Dhanapathi, H.; Dutta, T.K.; Sujiv, A. Prevalence and predictors of delayed gastric emptying among Indian patients with long-standing type 2 diabetes mellitus. Indian J. Gastroenterol. 2016, 35, 385-392. [CrossRef] [PubMed]

62. Talley, N.J.; Locke, G.R.; Lahr, B.D.; Zinsmeister, A.R.; Tougas, G.; Ligozio, G.; Rojavin, M.A.; Tack, J. Functional dyspepsia, delayed gastric emptying, and impaired quality of life. Gut 2006, 55, 933-939. [CrossRef] [PubMed]

63. Cherian, D.; Sachdeva, P.; Fisher, R.S.; Parkman, H.P. Abdominal pain is a frequent symptom of gastroparesis. Clin. Gastroenterol. Hepatol. 2010, 8, 676-681. [CrossRef] [PubMed]

64. Karamanolis, G.; Caenepeel, P.; Arts, J.; Tack, J. Determinants of symptom pattern in idiopathic severely delayed gastric emptying: Gastric emptying rate or proximal stomach dysfunction? Gut 2007, 56, 29-36. [CrossRef] [PubMed]

65. Pathikonda, M.; Sachdeva, P.; Malhotra, N.; Fisher, R.S.; Maurer, A.H.; Parkman, H.P. Gastric emptying scintigraphy: Is four hours necessary? J. Clin. Gastroenterol. 2012, 46, 209-215. [CrossRef] [PubMed]

66. Vijayvargiya, P.; Jameie-Oskooei, S.; Camilleri, M.; Chedid, V.; Erwin, P.J.; Murad, M.H. Association between delayed gastric emptying and upper gastrointestinal symptoms: A systematic review and meta-analysis. Gut 2019, 68, 804-813. [CrossRef]

67. Parkman, H.P.; Hallinan, E.K.; Hasler, W.L.; Farrugia, G.; Koch, K.L.; Nguyen, L.; Snape, W.J.; Abell, T.L.; McCallum, R.W.; Sarosiek, I.; et al. Early satiety and postprandial fullness in gastroparesis correlate with gastroparesis severity, gastric emptying, and water load testing. Neurogastroenterol. Motil. 2017, $29,12981$. [CrossRef]

68. Janssen, P.; Harris, M.S.; Jones, M.; Masaoka, T.; Farré, R.; Törnblom, H.; Van Oudenhove, L.; Simrén, M.; Tack, J. The relation between symptom improvement and gastric emptying in the treatment of diabetic and idiopathic gastroparesis. Am. J. Gastroenterol. 2013, 108, 1382-1391. [CrossRef]

69. Richter, J.E.; Rubenstein, J.H. Presentation and Epidemiology of Gastroesophageal Reflux Disease. Gastroenterology 2018, 154, 267-276. [CrossRef]

70. Barshop, K.; Staller, K.; Semler, J.; Kuo, B. Duodenal rather than antral motility contractile parameters correlate with symptom severity in gastroparesis patients. Neurogastroenterol. Motil. 2015, 27, 339-346. [CrossRef]

71. Cogliandro, R.F.; Rizzoli, G.; Bellacosa, L.; De Giorgio, R.; Cremon, C.; Barbara, G.; Stanghellini, V. Is gastroparesis a gastric disease? Neurogastroenterol. Motil. 2019, 31, 13562. [CrossRef] [PubMed]

72. Vijayvargiya, P.; Camilleri, M.; Chedid, V.; Mandawat, A.; Erwin, P.J.; Murad, M.H. Effects of Promotility Agents on Gastric Emptying and Symptoms: A Systematic Review and Meta-analysis. Gastroenterology 2019, 156, 1650-1660. [CrossRef] [PubMed] 
73. Gourcerol, G.; Ouelaa, W.; Huet, E.; Leroi, A.M.; Ducrotte, P. Gastric electrical stimulation increases the discomfort threshold to gastric distension. Eur. J. Gastroenterol. Hepatol. 2013, 25, 213-217. [CrossRef] [PubMed]

74. Talley, N.J.; Locke, G.R.; Saito, Y.A.; Almazar, A.E.; Bouras, E.P.; Howden, C.W.; Lacy, B.E.; DiBaise, J.K.; Prather, C.M.; Abraham, B.P.; et al. Effect of Amitriptyline and Escitalopram on Functional Dyspepsia: A Multicenter, Randomized Controlled Study. Gastroenterology 2015, 149, 340-349. [CrossRef] [PubMed]

75. Parkman, H.P.; Van Natta, M.L.; Abell, T.L.; McCallum, R.W.; Sarosiek, I.; Nguyen, L.; Snape, W.J.; Koch, K.L.; Hasler, W.L.; Farrugia, G.; et al. Effect of nortriptyline on symptoms of idiopathic gastroparesis: The NORIG randomized clinical trial. JAMA 2013, 310, 2640-2649. [CrossRef] [PubMed]

76. Tack, J.; Caenepeel, P.; Fischler, B.; Piessevaux, H.; Janssens, J. Symptoms associated with hypersensitivity to gastric distention in functional dyspepsia. Gastroenterology 2001, 121, 526-535. [CrossRef]

77. Eshuis, W.J.; de Bree, K.; Sprangers, M.A.; Bennink, R.J.; van Gulik, T.M.; Busch, O.R.; Gouma, D.J. Gastric emptying and quality of life after pancreatoduodenectomy with retrocolic or antecolic gastroenteric anastomosis. Br. J. Surg. 2015, 102, 1123-1132. [CrossRef]

78. Sutcliffe, R.P.; Forshaw, M.J.; Tandon, R.; Rohatgi, A.; Strauss, D.C.; Botha, A.J.; Mason, R.C. Anastomotic strictures and delayed gastric emptying after esophagectomy: Incidence, risk factors and management. Dis. Esophagus 2008, 21, 712-717. [CrossRef]

79. Paul, S.; Escareno, C.E.; Clancy, K.; Jaklitsch, M.T.; Bueno, R.; Lautz, D.B. Gastrointestinal complications after lung transplantation. J. Heart Lung Transplant. 2009, 28, 475-479. [CrossRef]

80. Lu, D.; Altieri, M.S.; Yang, J.; Yin, D.; Obeid, N.; Spaniolas, K.; Talamini, M.; Pryor, A.D. Investigating rates of reoperation or postsurgical gastroparesis following fundoplication or paraesophageal hernia repair in New York State. Surg. Endosc. 2019, 33, 2886-2894. [CrossRef]

81. Chen, X.-D.; Mao, C.-C.; Zhang, W.-T.; Lin, J.; Wu, R.S.; Zhang, F.M.; Sun, X.W.; Chi, C.H.; Shen, X.; Wang, P.F. A quantified risk-scoring system and rating model for postsurgical gastroparesis syndrome in gastric cancer patients. J. Surg. Oncol. 2017, 116, 533-544. [CrossRef] [PubMed]

(C) 2019 by the authors. Licensee MDPI, Basel, Switzerland. This article is an open access article distributed under the terms and conditions of the Creative Commons Attribution (CC BY) license (http://creativecommons.org/licenses/by/4.0/). 